\title{
Immunohisto- and cytochemical localization of PR-10 proteins induced by heavy metals in lupine roots
}

\author{
R. Przymusiński • J. Gzyl
}

Received: 2 August 2012/Revised: 26 November 2012/Accepted: 30 November 2012/Published online: 25 December 2012

(C) The Author(s) 2012. This article is published with open access at Springerlink.com

\begin{abstract}
Most of the data concerning PR-10 proteins accumulation in plants under various environmental stress conditions are derived from biochemical analysis of transcript expression or polypeptide accumulation. In the current study, we examined the localization of PR (L1-L6) proteins, belonging to the PR-10 class family, in the root tips of yellow lupine seedlings using histo- and cytochemical methods. Immunohistochemical localization revealed the presence of PR-proteins in all examined yellow lupine root tip tissue, and lead treatment did not change the distribution of proteins in the roots. However, the metal induced a significant increase in the accumulation of PR-proteins in the meristematic cells and procambium tissue. An immunocytochemical approach with immunogold method demonstrated the cytoplasmic nature of the PR-proteins and their increased accumulation after copper treatment. The results confirmed the affiliation of PR (L1L6) to PR-10 class family proteins, as well as their intracellular localization.
\end{abstract}

Keywords Pathogenesis-related proteins . Immunodetection · PR-10 - Immunogold · Immunofluorescence $\cdot$ Lupinus luteus

Communicated by M. Hajduch.

R. Przymusiński ( $₫) \cdot J$. Gzyl

Laboratory of Plant Ecophysiology, Institute of Experimental

Biology, Faculty of Biology, Adam Mickiewicz University

in Poznań, Umultowska 89, 61-614 Poznań, Poland

e-mail: pr@amu.edu.pl

\section{Introduction}

One of the plant responses to metal ion toxicity is the synthesis of specific proteins and polypeptides, which increase cell tolerance to an excess of metal ions through modification of the cell metabolism. This group of proteins comprises phytochelatins, heat shock and desiccation proteins, various enzymes involved in the antioxidant defense system, and pathogenesis-related class 10 proteins (Clemens 2006; Nagajyoti et al. 2010; Sobkowiak and Deckert 2006). The vast majority of PR-10 class family proteins represent products of gene expression under bacterial or fungal pathogens stress conditions (Qiaojuan et al. 2008; van Loon et al. 1994; Walter et al. 1996). However, previous studies carried out on lupine seedling root tips showed that heavy metal ions, such as lead, copper, cadmium, zinc (Przymusiński and Gwóźdź 1994; Przymusiński et al. 2004) and chromium (unpublished data), strongly induce the synthesis and accumulation of $16 \mathrm{kDa}$ polypeptides. Sequence analysis of $20 \mathrm{~N}$-terminal amino acids indicated that all these polypeptides show a high degree of homology to the 10 class family of pathogenesisrelated proteins (Przymusiński and Gwóźdź 1999). These polypeptides are designated as PR-L1 to PR-L6, and their protein sequences have been introduced to the Swiss-Prot database. Regardless of the stress factor that induced PR-10 proteins, all of them exhibited high homology in amino acid sequences, as well as similarities in their physical and chemical properties. PR-10 family proteins are composed of roughly 153-163 amino acid residues with molecular weights in the range of 16-19 kDa (Sikorski 1997; Walter et al. 1990). Furthermore, members of the PR-10 group share several conserved features, including a lack of signal peptides and hydrophobic helices, acidic $\mathrm{p} I$ values of 4.5-6.5, and a high resistance to protease activity 
(Bantignies et al. 2000; Walter et al. 1990), and their glycine residues are important to the conformation of the highly conserved region called the glycine-rich P-loop (Saraste et al. 1990; Sikorski et al. 1999). Most PR-10 proteins are classified as intracellular proteins (Qiaojuan et al. 2008; van Loon et al. 1994); however, several authors point to their extracellular localization (Pinto and Ricardo 1995; Tamás et al. 1997). In our previous study, PR-10 proteins induced by lead ions in lupine seedlings were detected using a tissue printing method (Przymusiński et al. 2001). However, this approach was not able to provide accurate information about the localization of proteins in the root tips. Therefore, the aim of this study was to verify and detail the histological and cytological localization of PR-10 proteins in lupine root tips with a different immunolocalization approach.

\section{Materials and methods}

Yellow lupine seeds (Lupinus luteus cv. Ventus) selected on the basis of morphological features were sterilized in $70 \%$ ethanol for $5 \mathrm{~min}$ and in $20 \%$ Clorox for $10 \mathrm{~min}$, rinsed with distilled water and imbibed for $4 \mathrm{~h}$ in deionized water. The seeds were then germinated in plastic dishes lined with filter paper moistened with deionized water. Seedlings with primary roots approximately $10 \mathrm{~mm}$ in length were transferred to Petri dishes containing $5 \mathrm{~cm}^{3}$ of deionized water (control), an aqueous solution of $\mathrm{Cu}\left(\mathrm{NO}_{3}\right)_{2}$ at a $\mathrm{Cu}$ ion concentration of $16.5 \mathrm{mg} \mathrm{dm}{ }^{-3}$ or a $\mathrm{Pb}\left(\mathrm{NO}_{3}\right)_{2}$ solution at concentration of $\mathrm{Pb}$ ions $350 \mathrm{mg} \mathrm{dm}^{-3}$. The concentrations of the $\mathrm{Cu}\left(\mathrm{NO}_{3}\right)_{2}$ and $\mathrm{Pb}\left(\mathrm{NO}_{3}\right)_{2}$ solutions were chosen according to their previously estimated ability to inhibit root growth by $50 \%$ as compared to a control (Przymusiński and Gwóźdź 1994). The cultivation was carried out for $48 \mathrm{~h}$ in the dark at a temp. of $22{ }^{\circ} \mathrm{C}$.

Immunohistochemical localization of PR-10 proteins was carried out on root apexes including the meristematic zone. The excised roots were immediately fixed for $3 \mathrm{~h}$ in a phosphate saline buffer (PBS) containing $4 \%$ freshly prepared paraformaldehyde (PFA). The fragments were then dehydrated in a series of ethanol solutions and embedded in a mixture of polyethylene glycol 1500 and 4000 (2:1). Samples were sectioned at a thickness of 4-7 $\mu \mathrm{m}$ with a rotary microtome. Sections were blocked with $3 \%$ bovine serum albumin (BSA, Sigma) in PBS for $30 \mathrm{~min}$. The material was subsequently treated overnight at $4{ }^{\circ} \mathrm{C}$ with primary rabbit anti- $16 \mathrm{kDa}$ polyclonal antibody that had been diluted 1:12,000 with BSA/PBS. The samples were rinsed six times in PBS and then incubated at $37{ }^{\circ} \mathrm{C}$ for $2 \mathrm{~h}$ with Alexa Fluor 488-conjugated goat anti-rabbit (Molecular Probes) secondary antibody diluted 1:800 with $\mathrm{BSA} / \mathrm{PBS}$. After rinsing six times in PBS, the material was treated with propidium iodide (Sigma) for $5 \mathrm{~min}$ and mounted in an antifadent solution (Citifluor Ltd) on glass slides. Sections were observed with an LSM 510 confocal microscope (Carl Zeiss, Jena, Germany). On average, three different roots were investigated.

For immunocytochemical localization of PR-10 proteins, excised root tip fragments $(3 \mathrm{~mm})$ were immediately fixed in a mixture of $1 \%(\mathrm{v} / \mathrm{v})$ glutaraldehyde and $0.2 \%$ picric acid in $0.1 \mathrm{M}$ phosphate buffer $(\mathrm{pH} \mathrm{7.3)}$ ) for $2 \mathrm{~h}$ at room temperature (RT). After dehydration in a graded ethanol series, the material was embedded in LR White resin (Sigma). Ultrathin sections of the meristematic zone were placed on nickel mesh and then blocked in Trisbuffered-saline Tween 20 (TBST, pH 7.6) with $3 \%$ BSA for $45 \mathrm{~min}$ at RT. The sections were subsequently incubated overnight at $4{ }^{\circ} \mathrm{C}$ in a humid chamber either in one drop of primary anti-PR-10 antibody (1:150) in TBST/ $0.1 \%$ BSA or in pre-immune serum. An antibody against $16 \mathrm{kDa}$ polypeptide and a pre-immune serum were prepared according to the procedure of Przymusiński et al. (1995). After careful washing in TBST, the sections were incubated with $20 \mathrm{~nm}$ gold-labeled Protein A in TBST/1 \% BSA at RT for $2 \mathrm{~h}$. Afterward, the sections were washed with TBST and rinsed with distilled water to remove nonspecifically connected gold particles. The sections were examined with a JEM 1200 EX II (Jeol, Tokyo, Japan) transmission electron microscope (TEM). On average, three different roots were investigated.

\section{Results and discussion}

The presence or accumulation of prl0 genes expression products, mostly under stress conditions, has been demonstrated in roots and leaves (Bantignies et al. 2000; Przymusiński et al. 2004; Utriainen et al. 1998), hypocotyls (Gzyl et al. 1997), tuber (Flores et al. 2002), stems, seeds (Iturriaga et al. 1994), fruits (Andersen et al. 2011), embryos and pollen (Swoboda et al. 1994), stigma (Constabel and Brisson 1995), calluses (Moiseyev et al. 1997), and cell suspension (Carpin et al. 1998). These data suggest that PR-10 proteins might be potentially accumulated in all organs of plants and are in line with our earlier study (Przymusiński et al. 2001) in which the localization of PR (L1-L6) proteins with a tissue printing method was investigated in 12-day-old lupine seedlings, but excluding the root tips. Moreover, the vast majority of data concerning PR-10 proteins have been derived from biochemical methods, which analyzed the level of PR-transcript accumulation or the level of their polypeptide product expression, but this approach provided only quantitative data about PR-10 proteins. Histochemical localization using the immunofluorescence approach presented in this 
Fig. 1 Immunohistochemical localization of PR (L1-L6) proteins in the meristematic zone of yellow lupine root tips. The seedlings were growing in $\mathrm{H}_{2} \mathrm{O}$ (a) or an aqueous solution of $\mathrm{Pb}\left(\mathrm{NO}_{3}\right)_{2}$ at concentration $350 \mathrm{mg} \mathrm{dm}^{-3}(\mathbf{b})$. Immunofluorescence labeling was performed with anti-16PR (L1-L6) serum at a dilution of 1:12,000 and Alexa Fluor 488-conjugated goat anti-rabbit secondary antibody. Bar $100 \mu \mathrm{m}$
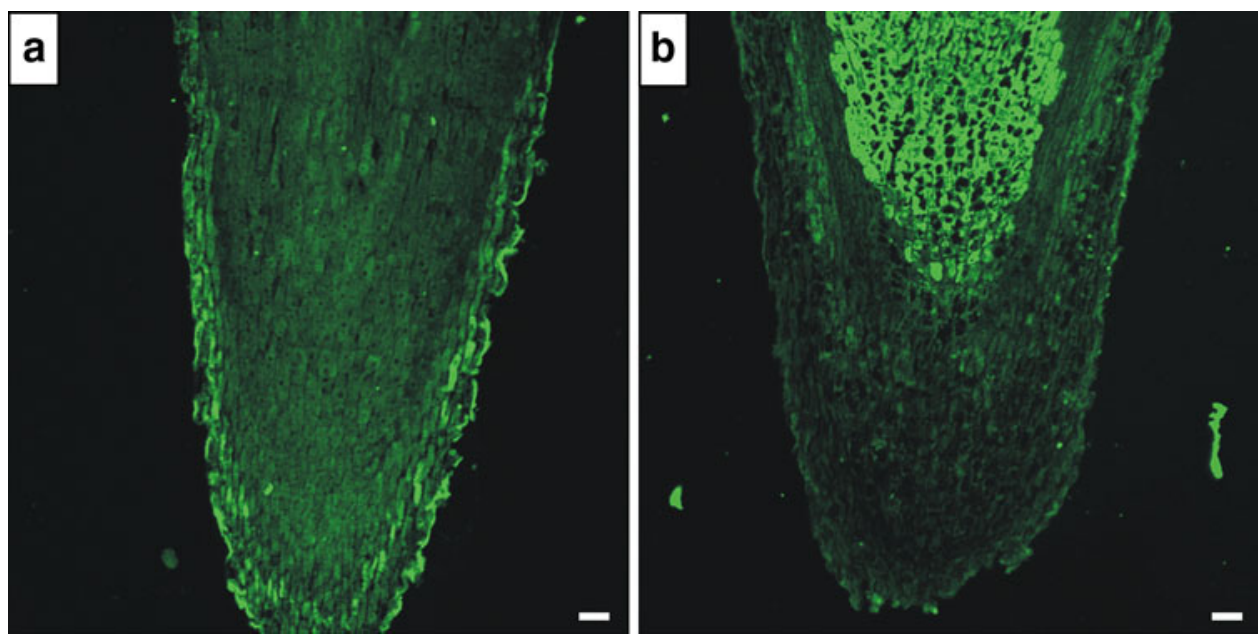

paper demonstrated the distribution of PR-10 in root tips. In control sections, a positive signal was detected in all tissues of root tips, but the most pronounced signal was observed in the perypherial cells of the calyptra (Fig. 1a). The other cells, including meristematic cells, procambium and the cells of ground meristem, exhibited a weaker and more or less uniformly distributed fluorescence signal. In lead-treated roots, the fluorescence signal was much stronger as compared to control roots, indicating a higher level of PR-10 proteins accumulation, and immunofluorescence was mainly distributed in the meristematic cells of the root tips as well as in the cells of the procambium (Fig. 1b). According to our knowledge, this is the first report on the histochemical distribution of PR-10 proteins in root tips using the immunofluorescence approach. Moreover, the increased level of the immunofluorescence signal in lead-treated roots provides additional evidence for the accumulation of PR-10 proteins under stress conditions. This result complements the previous studies carried out on lupine roots, where an increased level of free radicals (Rucińska et al. 1999) and superoxide dismutase activity (Przymusiński et al. 1995) was demonstrated in lead treated lupine seedlings. It has been proved that $\mathrm{H}_{2} \mathrm{O}_{2}$ induces gene expression of PR-proteins and their accumulation under lead treatment (Przymusiński et al. 2001, 2007).

In the next set of experiments, we localized the cellular sites of PR-proteins by the immunogold technique. Lupine seedlings were incubated in a solution of $\mathrm{Cu}$ instead of $\mathrm{Pb}$ to avoid electron-dense lead deposits in cells exposed to this metal, which could hinder the analysis of gold particles localization with transmission electron microscopy. However, our earlier studies have indicated that $\mathrm{Cu}$ ions increase the synthesis and accumulation of PR-10 proteins in a manner analogous to lead treatment (Przymusiński et al. 2004). In control root cells, the labeling was mainly distributed over the cytoplasm in the form of more or less evenly spaced gold particles (Fig. 2b). The rest of the cellular compartments, such as the cytoplasmic vacuoles (vesicles), mitochondria, endoplasmic reticulum, cell walls or intercellular spaces showed very few gold particles, corresponding to unspecific background binding. After copper treatment, the anti-PR-10 antibodies provided specific and significantly greater labeling as compared to the control cells (Fig. 2c , d), and the gold particles were distributed only in the cytoplasm area. The presented results revealed only cytoplasmatic localization of PR-10 proteins after treatment of lupine seedlings with heavy metal solutions. No binding of gold particles was observed when the sections were incubated with preimmune serum (Fig. 2a), which indicates that the observed labeling in lupine root cells is specific. Intracellular localization can result from both a lack of signal peptide and hydrophobic helices in PR-10 proteins, indicating their affiliation to soluble cytosolic protein fraction. The intracellular localization of PR-10 proteins has been confirmed by many investigators, but in those studies a biochemical approach was applied (Qiaojuan et al. 2008; Saraste et al. 1990; Sikorski 1997) and there is very little data concerning cytochemical localization of PR-proteins. For example, electron microscopic observations of immunogold-labeled leaves have revealed the localization of PR-p16.5 a, b and c proteins in Lupinus albus infected by Collototrichum gloeosporioides (Pinto and Ricardo 1995). Gold particles were predominantly localized in the cell wall, although a few gold particles could be found in the cytoplasm, so the cytoplasmatic localization of PR (L1-L6) proteins presented in our experiments is only partly in line with the results of PR-p16.5 distribution. However, the extracellular localization of PR-p16.5 proteins in light of their physical and chemical properties as well as amino acid sequences, which strongly suggests their intracellular nature related with pathogenesis, is unclear. Possible discrepancies in the 
Fig. 2 Immunocytochemical localization of PR (L1-L6) proteins in the meristematic cells of yellow lupine root tips. The seedlings were growing in $\mathrm{H}_{2} \mathrm{O}($ b) or an aqueous solution of $\mathrm{Cu}\left(\mathrm{NO}_{3}\right)_{2}$ at concentration $16.5 \mathrm{mg} \mathrm{dm}^{-3}$ (a, c, d). Immunogold labeling was performed with pre-immune serum (a) and anti-16PR (L1-L6) serum (b-d). CW cell wall, $V$ vacuoles,

$m$ mitochondrium, arrows gold particles. Bars $200 \mathrm{~nm}$ (a) $500 \mathrm{~nm}$ (b)
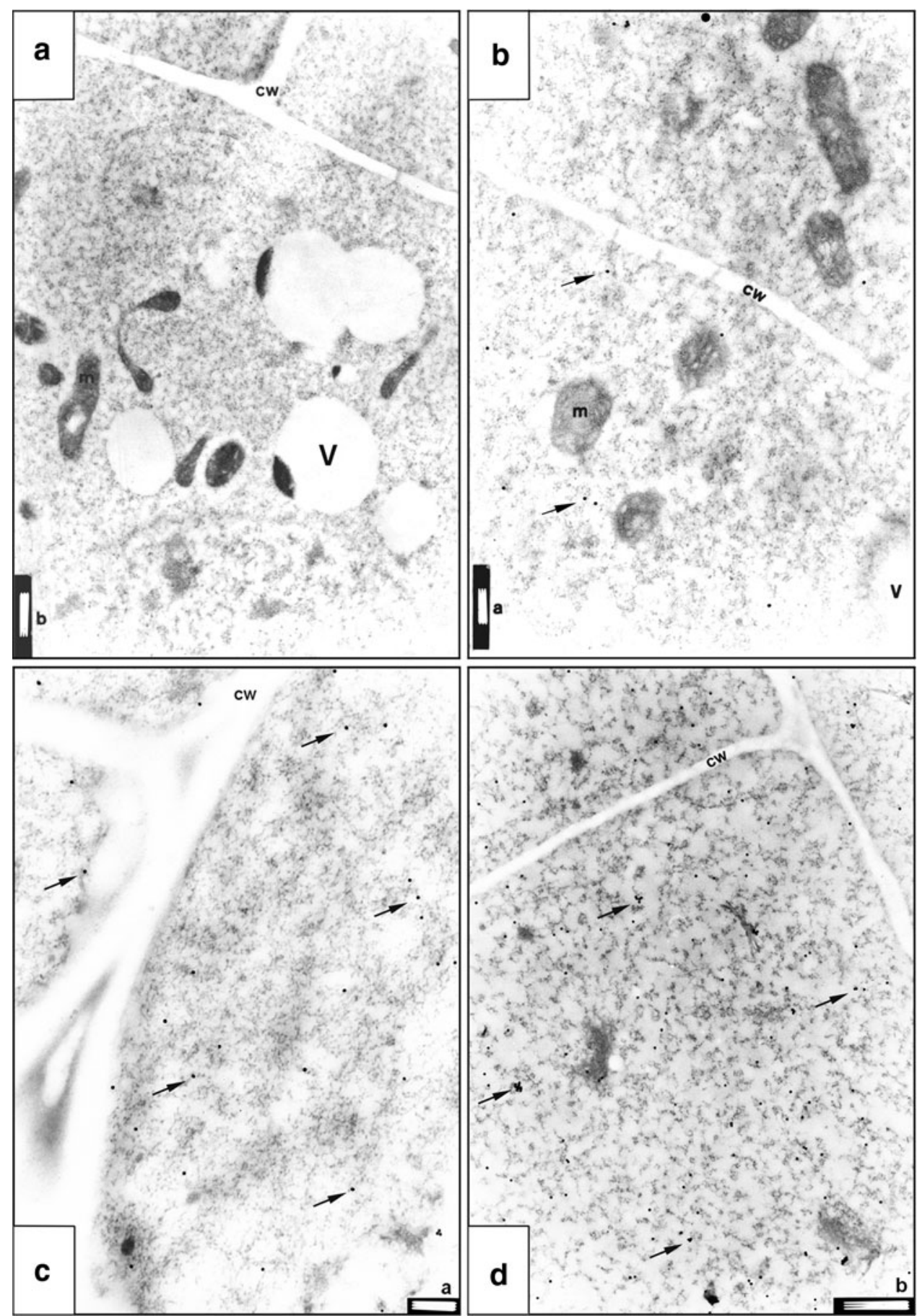

literature concerning the histological and cytological localization of PR-proteins can be plausibly explained when taking into account the multi-gene nature of the family encoding PR-10 proteins (Ekramoddoullah 2004) and their regulation during the plant's development. Thus, PR-10 proteins might be distributed in different plant tissues and their localization might change throughout the development process of specific organs. Taken together, the results presented in this paper obtained by means of the immunogold method seem to provide further evidence confirming the affiliation of PR (L1-L6) polypetides in lupine roots to PR-10 family proteins and their intracellular localization.

Author contribution R. Przmusiński and J. Gzyl designed and carried out the experiments, analyzed the data and wrote the manuscript. Both authors contributed equally to the work 
Open Access This article is distributed under the terms of the Creative Commons Attribution License which permits any use, distribution, and reproduction in any medium, provided the original author(s) and the source are credited.

\section{References}

Andersen MBS, Hall S, Dragsted LO (2011) Identification of European allergy patterns to the allergen families PR-10, LTP, and profilin from rosaceae fruits. Clin Rev Allergy Immunol 41:1-16

Bantignies B, Séguin J, Muzac I, Dédaldéchamp F, Gulick P, Ibrahim R (2000) Direct evidence for ribonucleolytic activity of a PR-10like protein from white lupin roots. Plant Mol Biol 42:871-881

Carpin S, Laffer S, Schoentgen F, Valenta R, Chénieux JC, Rideau M, Hamdi S (1998) Molecular characterization of a cytokinininducible periwinkle protein showing sequence homology with pathogenesis-related proteins and the bet $\mathrm{v} 1$ allergen family. Plant Mol Biol 36:791-798

Clemens S (2006) Toxic metal accumulation, responses to exposure and mechanisms of tolerance in plants. Biochimie 88:1707-1719

Constabel CP, Brisson N (1995) Stigma- and vascular-specific expression of the PR-10a gene of potato: a novel pattern of expression of a pathogenesis-related gene. Mol Plant-Microbe Interact 8:104-113

Ekramoddoullah AKM (2004) Physiology and molecular biology of a family of pathogenesis-related PR-10 proteins in conifers. J Crop Improv 10:261-280

Flores T, Alape-Girón A, Flores-Díaz M, Flores HE (2002) Ocatin. A novel tuber storage protein from the Andean tuber crop oca with antibacterial and antifungal activities. Plant Physiol 128:1291-1302

Gzyl J, Przymusiński R, Woźny A (1997) Organospecific reactions of yellow lupin seedlings to lead. Acta Soc Bot Pol 66:61-66

Iturriaga EA, Leech MJ, Barratt DHP, Wang TL (1994) Two ABAresponsive proteins from pea (Pisum sativum L.) are closely related to intracellular pathogenesis-related proteins. Plant Mol Biol 24:235-240

Moiseyev GP, Fedoreyeva LI, Zhuravlev YN, Yasnetskaya E, Jekel PA, Beintema JJ (1997) Primary structures of two ribonucleases from ginseng calluses: new members of the PR-10 family of intracellular pathogenesis-related plant proteins. FEBS Lett 407:207-210

Nagajyoti PC, Lee KD, Sreekanth TVM (2010) Heavy metals, occurrence and toxicity for plants: a review. Environ Chem Lett 8:199-216

Pinto MP, Ricardo CP (1995) Lupinus albus L. pathogenesis-related proteins that show similarity to PR-10 proteins. Plant Physiol 109:1345-1351

Przymusiński R, Gwóźdź EA (1994) Increased accumulation of the $16 \times 10^{3} \mathrm{M}_{\mathrm{r}}$ polypeptide on lupin roots exposed to lead, copper and nitrite ions. Environ Exp Bot 34:63-68

Przymusiński R, Gwóźdź EA (1999) Heavy metal-induced polypeptides in lupin roots are similar to pathogenesis-related proteins. J Plant Physiol 154:703-708

Przymusiński R, Rucińska R, Gwóźdź EA (1995) The stressstimulated $16 \mathrm{kDa}$ polypeptide from lupin roots has properties of cytosolic $\mathrm{Cu}: \mathrm{Zn}$-superoxide dismutase. Environ Exp Bot 35:485-495

Przymusiński R, Banaszak A, Gwóźdź EA (2001) Organospecific responses of lupin seedlings to lead I. Localization of lead ions and stress proteins. Acta Physiol Plant 23:109-116

Przymusiński R, Rucińska R, Gwóźdź EA (2004) Increased accumulation of pathogenesis-related proteins in response of lupine roots to various abiotic stresses. Environ Exp Bot 52:53-61

Przymusiński R, Rucińska-Sobkowiak R, Ilska B, Gwóźdź EA (2007) Organospecific responses of lupin seedlings to lead. Localization of hydrogen peroxide and peroxidase activity. Acta Physiol Plant 29:411-416

Qiaojuan Y, Xiaowei Q, Zhengqiang J, Shaoqing Y, Lujia H (2008) Characterization of a pathogenesis-related class 10 protein (PR10) from Astragalus mongholicus with ribonuclease activity. Plant Physiol Biochem 46:93-99

Rucińska R, Waplak S, Gwóźdź EA (1999) Free radical formation and activity of antioxidant enzymes in lupin roots exposed to lead. Plant Physiol Biochem 37:187-194

Saraste M, Sibbald PR, Wittinghofer A (1990) The P-loop-a common motif in ATP- and GTP-binding proteins. Trends Biochem Sci 15:430-434

Sikorski MM (1997) Expression of Lupinus luteus cDNA coding for PR10 protein in Escherichia coli: purification of the recombinant protein for structural and functional studies. Acta Biochim Pol 44:565-578

Sikorski MXM, Biesiadka J, Kasperska AE, Kopcińska J, Lotocka B, Golinowski WXX, Legocki AB (1999) Expression of genes encoding PR10 class pathogenesis-related proteins is inhibited in yellow lupine root nodules. Plant Sci 149:125-137

Sobkowiak R, Deckert J (2006) Proteins induced by cadmium in soybean cells. J Plant Physiol 163:1203-1206

Swoboda I, Scheiner O, Kraft D, Breitenbach M, Heberle-Bors E, Vicente O (1994) A birch gene family encoding pollen allergens and pathogenesis-related proteins. Biochim Biophys Acta, Gene Struct Expr 1219:457-464

Tamás L, Huttová J, Žigová Z (1997) Accumulation of stress-proteins in intercellular spaces of barley leaves induced by biotic and abiotic factors. Biol Plant 39:387-394

Utriainen M, Kokko H, Auriola S, Sarrazin O, Karenlampi S (1998) PR-10 protein is induced by copper stress in roots and leaves of a $\mathrm{Cu} / \mathrm{Zn}$ tolerant clone of birch, Betula pendula. Plant, Cell Environ 21:821-828

van Loon LC, Pierpoint WS, Boller T, Conejero V (1994) Recommendations for naming plant pathogenesis-related proteins. Plant Mol Biol Rep 12:245-264

Walter MH, Liu JW, Grand C, Lamb CJ, Hess D (1990) Bean pathogenesis-related $(\mathrm{PR})$ proteins deduced from elicitorinduced transcripts are members of a ubiquitous new class of conserved PR proteins including pollen allergens. Mol Gen Genet 222:353-360

Walter MH, Liu JW, Wünn J, Hess D (1996) Bean ribonuclease-like pathogenesis-related protein genes (Ypr10) display complex patterns of developmental, dark-induced and exogenous-stimulus-dependent expression. Eur J Biochem 239:281-293 